Article

\title{
Folklore and Sociolinguistics
}

\author{
John Holmes McDowell
}

Department of Folklore and Ethnomusicology, Indiana University, Bloomington, IN 47405, USA; mcdowell@Indiana.edu

Received: 16 November 2017; Accepted: 18 January 2018; Published: 22 January 2018

\begin{abstract}
Folklore and sociolinguistics exist in a symbiotic relationship; more than that, at points-in the ethnography of communication and in ethnopoetics, for example-they overlap and become indistinguishable. As part of a reaction to the formal rigor and social detachment of Chomsky's theoretical linguistics, sociolinguistics emerges in the mid-twentieth century to assess the role of language in social life. Folklorists join the cause and bring to it a commitment to in-depth ethnography and a longstanding engagement with artistic communication. In this essay, I trace key phases in the development of this interdisciplinary movement, revolutionary in its reorientation of language study to the messy but fascinating realm of speech usage. I offer the concept of performative efficacy, the notion that expressive culture performances have the capacity to shape attitude and action and thereby transform perceived realities, as a means of capturing the continuing promise of a sociolinguistically informed folkloristics.
\end{abstract}

Keywords: Verbal art and speech play; ethnopoetics; ethnography of speaking; performance; speech act theory; semiotics; oral-formulaic theory

\section{Introduction}

Many would say that language makes us human, and few would deny that language lies very close to the heart of human experience. But what is language? Is it Noam Chomsky's impeccable system of logical concatenations, housed in the human brain and accessible only to the idealized speaker-listener? Or is it a well-worn but always energized instrument, deployed strategically as people go about their business in the world? This is the question that provoked the rise of sociolinguistics and the ethnography of speaking, and that led in folkloristics to the formulation of the performance-centered paradigm, all directly or indirectly challenging the Chomskyan sequestration of language study to the formal rigor of generative grammar (Chomsky 1957, 1965). Folklorists and other scholars whose work is strongly ethnographic are immersed in the messiness of speech practice; we can appreciate the elegance of syntactic structures with their rules and formulas, but we are patently aware of the creativity, and passion, that speakers bring to the execution of this system, and indeed, it is to that arena of speech execution that we are relentlessly drawn. Granted, natural or ordinary language, fashioned over time in human communities, evinces a remarkable structure of logic-think of how gender and number agreement in English-language personal pronouns is causing such discomfort these days-but folklorists and others who attend to the spoken word know that this is only part of the story.

The story I want to tell in this essay is how this mid-twentieth-century rebellion against the confines of theoretical linguistics went on to blossom into a powerful intellectual nexus, with folklorists and the expressive forms we favor playing a central role in this far-reaching treatment of the social uses of language. We can seek roots for this twentieth-century florescence in adumbrations of earlier decades and centuries (Malinowski 1923; Boas 1925; Bauman and Briggs 2003), but my intent here is to trace the more immediate sources of inspiration as I identify insights emerging in the 1960s and 1970s that continue to inform and guide research on language in culture. 
The focus of this essay is on the multi-layered relationship between folkloristics and sociolinguistics, resulting in a strong sociolinguistic influence on folklore studies, and, equally, a significant folkloristic contribution to sociolinguistics; I will argue, in particular, that folklorists engaging in this project open a perspective on the intersection of poetic elaboration and rhetorical impact. In his 1971 essay titled "The Contribution of Folklore to Sociolinguistic Research," Dell Hymes, the central player in our tale and a major figure in both folkloristics and anthropology, describes the focus of sociolinguistics as "the place of language in social life" and notes that folklore studies, "more than any other discipline," is suited to explore "the creative aspect of language use" (Hymes 1971, pp. 42, 49). Folklore, Hymes states, can contribute by tracking the "social and expressive aspects of speech," and do so, as he argues in a later piece, by working from within, starting "with community definitions of situation, activity, purpose, and genre" (Hymes 1975a, p. 350). Hymes' prescient comments will guide the present account of the interplay of these two fields, and I will propose performative efficacy, a concept linking speech settings, verbal stylization, referential depth, and the capacity of speech to make things happen in the world, as one way to highlight the important contributions of this intellectual movement.

\section{A Mid-Century Crossroads of Ideas}

We visit a crossroads that draws together fruitful thinking in many closely related and also more disparate fields - sociology, ethnomethodology, anthropology, linguistics, literary criticism, classical studies, communication studies, ordinary language philosophy, and semiotics, to name the most salient of these. In sociology, one thinks of Basil Bernstein's dissection of British speech into elaborated and restricted codes (Bernstein 1971); of Erving Goffman's novelistic deconstruction of social interaction (Goffman 1967); and of William Labov's treatment of language variation (Labov 1966) and of verbal virtuosity among inner-city black youth (Labov 1972). Anthropology is an especially important partner; anthropological linguistics, developed from the work of Franz Boas and his students and their efforts to describe and document the endangered languages of North America, and linguistic anthropology, tied to the programmatic statements of Dell Hymes (1974), constitute important tributaries to this intellectual stream. Especially attractive to folklorists are such works in this anthropological vein as Dennis Tedlock's program for attending to the acoustic textures of oral communication (Tedlock 1971, 1972) and Keith Basso's treatment of joking imitations among the Western Apache (Basso 1979).

Intersecting fruitfully with these projects in disciplines adjacent to folkloristics are outliers such as John Austin's argument that speech should be seen as a form of action (Austin 1962) and John Searle's development of speech act theory, building on Austin's insights (Searle 1969). Within the folkloristic workshop, the impact of Milman Parry's and Albert Lord's work on oral epic, manifested in Lord's The Singer of Tales (1960), cannot be overstated. In addition, we should take note of a number of folkloristic anticipations of a focus on the social use of language (for example, Bascom 1955; Jansen 1957; List 1963; Paredes 1964; Dundes 1964; Dégh 1969; Georges 1969; Toelken 1969). Underlying all these projections we will find the seminal ideas of thinkers such as Roman Jakobson $(1960,1966,1968)$, with his remarkable three-phrased academic career, and Kenneth Burke (1941), a poet and student of poetics. In addition, linguistics re-enters the conversation with a subfield, pragmatics, directed toward contextual factors in speech usage (Silverstein 1976; Van Dijk 1977; Brown and Levinson 1978; Hanks 1987).

These variegated threads of commentary on language as a social resource are stitched together into a folkloristic enterprise as our field transitions from text-orientation to behavior-orientation in the last quarter of the twentieth century, putting into place a contextual approach to verbal performance (Ben-Amos 1971; Bauman 1971). Drawing on this confluence of ideas, the generation of folklorists coming of age in this period crafts a folkloristic project with sociolinguistic factions, with the following premises: that language is realized through speech, as Ferdinand de Saussure (1959) held, and hence speech is the proper object of study; that speech naturally occurs in real-world verbal performances; that these performances are creative and emergent, guided but hardly controlled by generic conventions; and, crucially, that verbal performances are not merely reflections of social 
conditions, but that they frequently shape and can actually constitute these conditions (Rosaldo 1972; Bauman 1992). The folkloristic emphasis on aesthetics, on stylized expression, complements and enriches the sociolinguistic focus on language usage and locates verbal activity at the junction of poetics and rhetoric, as Roger Abrahams (1968, 1993, 2005) proposes, drawing on Kenneth Burke's formulations of literary purpose.

This folkloristic project takes shape gradually over the last quarter of the twentieth century in the work of many folklorists and fellow travelers, but it is possible to identify a few key moments along the way. Dell Hymes (1964a) announces a new field, the ethnography of communication, and the 1964 collection of essays, Language in Culture and Society: A Reader in Linguistics and Anthropology, edited by Hymes, offers a global compendium of speech practices documented by dozens of ethnographers in its 764 pages (Hymes 1964b). Another omnibus collection along these lines is Directions in Sociolinguistics: The Ethnography of Communication assembled by John Gumperz and Hymes and published in 1972 (Gumperz and Hymes 1972). A cornerstone in the consolidation of an ethnography of speaking with folkloristic tendencies is the 1972 gathering of scholars in Austin, Texas, that results in the wide-ranging essays in Explorations in the Ethnography of Speaking. This conference and its resulting anthology, edited by Richard Bauman and Joel Sherzer and published in 1974 (Bauman and Sherzer 1974), puts on display the central role of folklorists in pulling together the separate strands of work on language as a social phenomenon into a focused paradigm that has motivated and sustained research up to the present day. A particularly salient marker is the 1978 publication of Bauman's Verbal Art as Performance, with its companion pieces by Roger Abrahams (1978), Barbara Babcock (1978), Gary Gossen (1978), and Joel Sherzer (1978), the first comprehensive programmatic statement delineating the outlines of this emerging perspective in folklore studies.

\section{Selected Points of Departure}

We will benefit from a closer look at selected points of departure to trace the conceptual framework of this fusing of folkloristics and sociolinguistics. I have selected six of these for treatment here on the basis of my own adventures in a folkloristics devoted to the study of language use; another writer would likely make different selections, and I am conscious of excluding a good many worthy antecedents. However, here are the six that stand out in my reading of the literature:

1. Semiotics. The semiotics of Ferdinand de Saussure is a convenient starting point-his insistence, already noted, that speech is the proper object of study; that langue, the social side of language, and parole, its individual realization, are intertwined but distinguishable; that we should attempt to understand specific moments in time in the context of all their active variables; and that each sound or phrase acquires meaning through its placement in a larger scheme. This set of ideas forms the foundation for the structuralist movement that sweeps through the humanities in the mid-twentieth century, and also for the development of modern linguistics; it is influential as well in folklore studies, tying into a synchronic focus that arises to complement the longstanding diachronic orientation in our field.

2. Roman Jakobson's poetics. Jakobson, the Russian folklorist, literary scholar, and linguist, offers through his poetics another important point of departure. Jakobson, in association with his colleagues in the Prague Circle of Linguistics (Garvin 1964), provides a scheme for identifying the core factors and functions of human communication with special attention to its artistic or aesthetic components. Jakobson's thesis on the poetic function of language, highlighting the patterning of linguistic resources in speech production, tallies well with the folklorist's dedication to aesthetics and becomes a foundation for formal analysis in folkloristic treatments of verbal art performances. This formulation, locating poetic elaboration in the sequential patterning of like elements, reads as follows: "the poetic function projects the principle of equivalence from the axis of selection into the axis of combination" ((Jakobson 1960, p. 358), Italics in original).

3. Oral-formulaic theory. Equally iconic for folklorists is Albert Lord's definition of the formula in South Slavic oral epic performance. In Lord's The Singer of Tales (1960) we encounter the verbal 
artist who can tailor a performance to the mood of the audience, extending passages that are being well received and curtailing the less effective ones. Lord's model of composition during performance, wherein the performer improvises on the basis of a set of traditional resources, proves to be formative in subsequent folkloristic theorizing on performance. At the heart of his discussion is the formula, the building block of oral-formulaic composition, delineated by Lord as follows: "an expression that is regularly used, under the same metrical conditions, to express a particular essential idea" (Lord 1960, p. 4). Even if oral epic stands apart as a distinctive poetic genre, Lord's discussion of verbal improvisation, shaped by contextual factors and guided by acquired skills within a generic system, proves to be revelatory and applicable to performance in many, perhaps all, expressive genres (McDowell 1972).

4. William Labov's sociolinguistics. Labov's study of the social stratification of language and his work with inner city black youth in Philadelphia begin in sociolinguistics but venture into folkloristics as he takes up narrative and verbal dueling as loci for his research. Labov's quest for a method to map phonological variation takes him to narrative performance as a space where the intrusive impact of speaker self-correction is likely to be less active. In particular, stories with a gripping thematic, such as accounts of brushes with mortality, will evade this tendency to produce "correct" speech and hence reveal the speaker's normal speech patterns. This excursion into narrative leads Labov, initially in partnership with Joshua Waletzky and later on his own, to formulate a definition and componential model of narrative that have proved to be quite influential among folklorists (Labov and Waletzky 1967; Labov 2013). In his efforts to document the verbal skills of Philadelphia teenagers, Labov develops a trenchant analysis of the ritual insult tradition known variously as sounding and playing the dozens. On the basis of ample ethnographic field data, Labov (1972) demonstrates that the young men he studies are skilled in speech production when encountered on their own cultural turf. Labov (1972, pp. 343-44) offers a model for sounding that has been well received by folklorists: he proposes that one sound leads to another, creating a game-like interplay, and that the key to containing the potential aggravation in these insults, that is, to keeping the insults ritual rather than actual, is to sustain the appropriate symbolic distance, meaning that references to actual vulnerabilities must be avoided. In these contributions, Labov brings the formalistic rigor of linguistics to bear on the materials of folklore study, offering valuable insights while preserving the vitality of the source material.

5. Speech act theory. Another resonant point of departure is the formulation of speech act theory, originating in the transformative thinking of the British ordinary language philosopher John Austin. In a series of lectures later published as How to Do Things with Words (1962), Austin shifts the focus of language inquiry from the truth value of communication to its appropriateness. The question, he argues, shouldn't be, is this statement true or false, but rather, is this statement a felicitous execution of the speech act it purports to be? Underlying this shift of focus are the premises that language is a form of social action and that every utterance must be viewed as a speech act. Some utterances are speech acts on their surface: think "I promise you" or "I bet you." Among these explicit speech acts are the performative ones, those that actually transform a situation, as in the priest or preacher stating "I now pronounce you man and wife" at the appropriate moment of a wedding ceremony. But even utterances that lack overt formulation as speech acts possess, according to Austin, an implicit speech act quality; hence, he who says, "It's hot today" can be understood to be asserting that it is a hot day, and asserting is a form of speech action. On these premises Austin constructs an ambitious framework, featuring what he calls felicity conditions, that is, the details of speaker identity and intent and of utterance form that must obtain if the speech act is to be successfully realized, as well as a sequence of stages in the implementation of the speech act, through which it gathers locutionary force by virtue of the words spoken; illocutionary force by virtue of the intended effect of the utterance; and, finally, perlocutionary force, measured in the effect of the utterance on the addressee. It falls to J. L. Austin's student, John Searle (1969), to flesh out Austin's schematic formulation to create 
a fully operational paradigm, featuring the core concepts of speech act, speech event, and speech community, so productive for scholars engaged in the analysis of artistic verbal communication with roots in traditional genres (Finnegan 1969; Foster 1974; McDowell 1979; Rosaldo 1982; Yankah 1991).

6. Dell Hymes' signature contributions. It would be an understatement to characterize the work of Dell Hymes as a point of departure, since he effectively sets the agenda for doing systematic research on verbal forms of expression. Hymes brings his training in language and literature into contact with his mission to recuperate Native American verbal repertoires, resulting in two expansive projects that have helped shape contemporary folkloristic work. One of these projects takes form as the ethnography of speaking; the other is the formulation of an ethnopoetics aimed at recognizing and restoring marginalized expressive repertoires. Hymes is normally taken to be an anthropologist, but like Franz Boas, Roman Jakobson, William Bascom, Richard Bauman, and others referenced here, he is just as easily seen to be a folklorist-such is the intertwining of these academic projects and identities. Hymes' systematic approach to verbal communication can be captured in his SPEAKING mnemonic, a robust checklist for tracking situational as well as formal features of a speech event (Hymes 1972). The ethnopoetics work seeks to recognize the literary value in storytelling and other verbal forms of Native and Indigenous peoples, in particular the Native peoples of Hymes' beloved Oregon. Hymes' articulation of what he calls "breakthrough into performance", moments when a dispassionate account transitions into a dramatic replaying, has been particularly influential with folklorists (Hymes 1975b, 1981). There is no exaggeration in saying that these two projects, largely created and curated by Dell Hymes-the ethnography of speaking and ethnopoetics-have guided and inspired folkloristic work on verbal genres over the last five decades (Kroskrity and Webster 2015).

\section{The Folkloristic Contribution}

We folklorists often perceive our field as an importer of theories and concepts from other fields, and doubtless, we have made good use of analytical frameworks originating in adjacent fields. In the case of a sociolinguistics focused broadly on the social use of language, we have borrowed, surely, but it can be argued that we have bestowed in equal measure. Charles Briggs $(2008$, p. 96) sees folkloristics as entering into "dialogic zones with existing disciplines," and that state of reciprocal exchange is much in evidence in its collaboration with sociolinguistics. In this section, I want to highlight the important synthesizing role played by folklore scholars in fashioning from diverse resources a cohesive scholarly program addressing our own concerns and materials, a program that has been well received by our colleagues in the social sciences and humanities (Rudy 2002). This scholarly program comes to center on the study of verbal performance as a form of situated artistic expression with the potential to constitute and transform society.

In the world of folklore studies, there are many moments and players in the making of this research agenda, but we can select Richard Bauman's 1978 book, Verbal Art as Performance, as a marker that announces the arrival of the project and sets out an agenda for it. Bauman, as we have noted, helped organize the Austin conference that led to Explorations in the Ethnography of Speaking (1974). He also served as guest editor for the 1971 special issue of the Journal of American Folklore titled "Toward New Perspectives in Folklore," which set forth behavioral and contextual approaches to folklore study. His own research on speech forms in several communities prepared him to think cohesively about the social use of language, and Verbal Art as Performance, founded on an article he published in 1974 in the American Anthropologist, affords him the opportunity to distill his thinking into this widely read and highly influential research manifesto. Even as this book stakes out a project of moment for folklorists, it alerts scholars in adjacent fields to a cohesive program centered on the expressive genres that folklorists study.

The core tenets of Verbal Art as Performance merit our attention. These chapter titles convey the drift of the project: "The Nature of Performance," "The Keying of Performance," "The Patterning 
of Performance," and "The Emergent Quality of Performance." In the first of these, Bauman offers his now famous definition of performance, coining a phrase we can set beside Jakobson's on the poetic function and Lord's on the formula as folkloristic icons: "performance as a mode of spoken verbal communication consists in the assumption of responsibility to an audience for a display of communicative competence" (Bauman 1978, p. 11). This concept of performance foregrounds stylistics, that is to say, the artistic dimension of communication, since "the act of expression on the part of the performer is ... marked as subject to evaluation for the way it is done, for the relative skill and effectiveness of the performer's display of competence." This formulation builds on the work of Gregory Bateson (1972) and Erving Goffman (1974) with frames and framing to define performance as a distinctive frame of social interaction with its own unique identifying features.

Bauman's treatment of keying reinforces this engagement with performance as a transaction within a social context by enumerating several cues that the performance frame is to be activated, ranging from, ironically, a disclaimer of performance to verbal formulas that identify the particular genre to be activated. The chapter on patterning is founded on the work of Roman Jakobson and his Prague School associates such as Jan Mukarovsky (1964), and points to the prominence in verbal art performances of recurring figures, in the sound, grammar, and diction of language. Finally, Bauman's discussion of emergence wrestles with a core folkloristic problem, the interplay of tradition and invention in crafting verbal performances.

This conceptual framework, grounded in pertinent examples culled from Bauman's own research and from the work of his colleagues, places the folkloristic approach to language in culture upon a new plateau, and the companion essays in the book offer detailed case studies that flesh out Bauman's programmatic statements. This book is both a culmination-of a growing but dispersed body of research that had been accumulating since the 1960s_and a commencement, in that it proposes a paradigm that can guide scholarly work into the future. Bauman himself continues to refine and extend this paradigm, in his own publications and in an important set of works that he co-authors with Charles Briggs (Bauman and Briggs 1990; Briggs and Bauman 1992). One line of inquiry in this subsequent work usefully employs the concept of intertextuality, the idea that every text stands in significant relation to other texts, in addressing verbal art rooted in local traditions (Bakhtin 1981; Bauman 2004).

\section{Performative Efficacy}

I will now spotlight a project that has emerged in my own thinking as a valuable extension of the perspectives we have been reviewing, namely the concept of performative efficacy, that is, the notion that expressive culture performances, when properly executed, have the capacity to transform perceived realities. The uttering of words, as John Austin (1962) demonstrated, is an action that produces consequences. The folkloristic turn involves locating utterances in their local contexts, tracking the genre conventions that are invoked, tracing the stylistic effects present in the medium of expression, and assessing the link of the utterance's referential content to relevant belief systems. It is the interplay of these formal, semantic, and situational factors that endows the utterances of expressive culture with their social impact, with their capacity to influence and shape attitude and action, and, in certain settings, to virtually alter material reality.

A good deal of research indicates a correlation between levels of speech formalization and levels of efficacy attaching to verbal expressions (Frake 1964; Turner 1969; Bloch 1974; Tedlock 1976; McDowell 1992; Yankah 1995). One way to capture this correlation is to highlight a continuum of speech events ranging from highly informal to highly formal settings, recognizing, as Judith Irvine (1979) alerts us, that these are fluid concepts with multiple facets to them. We can place routine conversation at one pole, and religious litany and other ritual discourse at the other, with ceremonial forms of various kinds falling in appropriate spots in between. Though these calibrations are hardly precise, this approach provides a generalizable model that can assist in ordering and exploring the data on the world's variable speech systems. A feature of this model, consistent with reports on many speech communities, 
is an increase in levels of speech formalization as we move from the informal to the formal end of this continuum (Fox 1974; Peek 1981; Feld 1982; Glassie 1982; Sherzer 1983; Urban 1986; Briggs 1988). That is to say, in many speech communities the available resources of the medium of expression-its acoustic, grammatical, and semantic features-evince higher levels of patterning and elaboration as we progress from casual speech settings to the more formally organized ones. Likewise, we often encounter higher levels of speech efficacy as we shift our position from the informal to the formal end of the continuum. Performativity, the ability of the spoken word to make things happen, is present as a potential in all speech acts, but levels of speech efficacy are variable depending on the type of speech event, and, naturally, on its felicitous execution according to the speech community's standards. Another correlation is often present in the transition from casual to more formal settings-decreasing levels of intelligibility, as the discourse becomes increasingly opaque, especially in ritual settings (Tambiah 1968; Murray 1977; Feld 1982; McDowell 1983; Brown 1984; Yankah 1991).

Allow me to illustrate these components of performative efficacy by briefly referencing my own work in speech play and verbal art. In a discussion of conversation's poetic rites (McDowell 1985), I argue that conversation, although often seen as primarily a venue for the straightforward exchange of information (Grice 1978), is nonetheless hospitable to poetic expression, and I refer here to all conversational settings, not just those given over to playful and frivolous banter. My argument is that key moments in conversational encounters-greetings and leave-takings, turn shifts, and points of topical migration-are loaded with uncertainty and hence ritual danger. My inspiration here is Erving Goffman's observation that "Once the exchange of words has brought individuals into a jointly sustained and ratified focus of attention, once that is, a fire has been built, any visible thing (just as any spoken referent) can be burnt in it" (Goffman 1981, p. 37). I document in my 1985 article the role of proverbs and proverbial expressions in neutralizing these precarious moments in conversations-by drawing on traditional wisdom, and introducing stylized and metaphoric speech segments into the flow of conversation, speakers navigate these points of ritual danger and promote the smooth accomplishment of conversation.

Performativity in conversational discourse is essential to social life but operates at a modest level of engagement-after all, conversation cannot tolerate large doses of poeticizing and still retain its defining characteristic as an open, egalitarian, and largely spontaneous forum for the exchange of information (Gumperz 1982; Tannen 1989). The level of performative efficacy is mild here, restricted to, in Goffman's terms, maintaining the social face of participants and avoiding ruptures in social interaction that would require repair (Goffman 1967). As we take up ceremonial and ritual speech events, we can expect to find higher levels of efficacy, fueled by higher levels of speech elaboration, though we need to bear in mind the variability of the world's speech taxonomies-I point to tendencies, not universals, and welcome notice of exceptions to these trends.

Speech-making in ceremonial settings, as I have witnessed in ceremonial speech forms of the Andes ( McDowell 1983, 1990), is likely to display a number of salient features: stylized acoustic contours, often endowed with palpable speech rhythms and intonational patterns; grammatical formations shaped by parallelism into recurrent structures; and special vocabularies and figurative language that resonate with deeply rooted beliefs and values (Kermode 1979; Foley 1991). Ceremonial speech forms evince an efficacy that goes beyond the immediate setting, enabling speakers to gain influence by triggering emotional response and validating the community itself as an idealized construction (George 1993). Performances of heroic song of the sort documented in the work of Milman Parry and Albert Lord and many others can be placed alongside ceremonial speech-making, since they can achieve, through the combination of musical textures and heroic vision, an efficacy we might call commemorative, validating the living community through evocation of its distinguished past (McDowell 2000). Finally, in speech events that occur within rituals, the efficacy of performative speech can approach and realize, at least in the minds of believers, a transformation of social and even physical realities_rites of passage remake the social order (Van Gennep 1960; Turner 1969), and rituals with 
a strong religious or spiritual mission are sometimes understood to reconfigure experienced reality (Rosenberg 1970; Brown 1984).

Performative efficacy is one way of capturing what Richard Bauman $(2015$, p. 177) calls "the radical insight of the ethnography of speaking - that speakers use their voices to accomplish things in the world." Whether in the casual exchanges of conversation or in the more scripted discourse of ceremony and ritual, people produce speech to make things happen in the world, and the appropriate dosage of stylization, as well as the evocation of communal values, is often the active ingredient in these transformations.

\section{Conclusions}

We have traced the emergence of sociolinguistics as a response to Chomsky-inspired theoretical linguistics with its generative grammars; sociolinguistics arises to ascertain how language actually operates in society, with close attention to language variation, to the influence of social setting on speech production, and to the interplay of languages, dialects, and idiolects in complex modern societies. The ethnography of speaking evolves in tandem with this project as scholars attempt to document the world's speech practices through close observation of actual speech events in targeted communities, often by producing speech taxonomies that describe a community's ways of speaking in relation to stylistic conventions and social occasions (Gossen 1971, 1978; Sherzer 1983). These developments mark an intellectual revolution that relocates the study of language in the social arenas where people deploy, refine, and reshape the linguistic resources at their disposal.

Enter the folklorist with expertise in the study of situated artistic communication, and the scene is set for cultivating an oral poetics (Bauman 2002, p. 94) that attends to the production and reception of stylized discourse in performance arenas where aesthetic elaboration has instrumental value. As Dell Hymes noted in his presidential address to the American Folklore Society in 1974, our longstanding engagement with genre, tradition, art, and performance, and our deep connections to the communities we study, enable us to make unique and needed contributions to understanding language as a social resource (Hymes 1975a). The result is an ethnography of speaking folklore that has enriched the wider discussion and fostered inspired work by a good many folklorists.

It is my hope and belief that this intellectual paradigm, with its articulation of performance as the key moment in the production and circulation of culture, will continue to inspire rewarding scholarly effort in the coming years. There is evidence of its continuing relevance in current folkloristics (see for example, Cara 2003; Cocq 2015; Mould 2005; Cashman 2011; Gravot 2015; Savoleinen 2017). The spoken word, and its written derivatives in such online venues as Twitter posts, remains at the center of social life in the world's societies. Verbal forms of expressive culture continue to figure in the political and spiritual life of the world's peoples, and forms of talk connect and separate people just as they have in the past. Given the prominence of speech across the whole range of human experience, we stand to benefit from a research paradigm that allows us to inspect and analyze the role of verbal performances in achieving and challenging social connectivity. Within this concerted flow of spoken language, the expressive forms that have occupied the attention of folklorists for centuries have their own special place, and a folkloristics that is attuned to performative efficacy must necessarily continue to offer valuable insights into the conduct of human affairs.

Acknowledgments: I am grateful for financial support from the John Simon Guggenheim Foundation, from the Fulbright Program, and from the College of Arts and Sciences at Indiana University.

Conflicts of Interest: The author declares no conflicts of interest.

\section{References}

Abrahams, Roger. 1968. Introductory Remarks to a Rhetorical Theory of Folklore. Journal of American Folklore 81: 143-58. [CrossRef] 
Abrahams, Roger. 1978. The Training of the Man of Words in Talking Sweet. In Verbal Art as Performance. Edited by Richard Bauman. Prospect Heights: Waveland Press, pp. 117-32.

Abrahams, Roger. 1993. After New Perspectives: Folklore Study in the Late Twentieth Century. Western Folklore 52: 379-400. [CrossRef]

Abrahams, Roger. 2005. Everyday Life: A Poetics of Vernacular Practices. Philadelphia: University of Pennsylvania Press. Austin, John. 1962. How to Do Things with Words. Cambridge: Harvard University Press.

Babcock, Barbara. 1978. The Story in the Story: Metanarration in Folk Narrative. In Verbal Art as Performance. Edited by Richard Bauman. Prospect Heights: Waveland Press, pp. 61-80.

Bakhtin, Mikhail. 1981. The Dialogic Imagination: Four Essays. Translated by Caryl Emerson, and Michael Holquist. Edited by Michael Holquist. Austin: University of Texas Press.

Bascom, William. 1955. Verbal Art as Folklore. Journal of American Folklore 68: 245-52. [CrossRef]

Basso, Keith. 1979. Portraits of "The Whiteman": Linguistic Play and Cultural Symbols among the Western Apache. Cambridge: Cambridge University Press.

Bateson, Gregory. 1972. A Theory of Play and Fantasy. In Steps to an Ecology of the Mind. New York: Ballantine, pp. 177-93.

Bauman, Richard. 1971. Introduction toward New Perspectives in Folklore. Journal of American Folklore 84: v-ix. Bauman, Richard. 1978. Verbal Art as Performance. Prospect Heights: Waveland Press.

Bauman, Richard. 1992. "Performance". In Folklore, Cultural Performance, and Popular Entertainments. Edited by Richard Bauman. Oxford: Oxford University Press, pp. 41-49.

Bauman, Richard. 2002. Disciplinarity, Reflexivity, and Power in Verbal Art as Performance: A Response. Journal of American Folklore 115: 92-98. [CrossRef]

Bauman, Richard. 2004. A World of Others' Words: Cross-Cultural Perspectives on Intertextuality. Malden: Blackwell Publishing.

Bauman, Richard. 2015. Discovery and Dialogue in Ethnopoetics. In The Legacy of Dell Hymes: Ethnopoetics, Narrative Inequality, and Voice. Edited by Paul Kroskrity and Anthony Webster. Bloomington: Indiana University Press, pp. 164-79.

Bauman, Richard, and Charles Briggs. 1990. Poetics and Performance as Critical Perspectives on Language and Social Life. Annual Review of Anthropology 19: 59-88. [CrossRef]

Bauman, Richard, and Charles Briggs. 2003. Voices of Modernity: Language Ideologies and Social Inequality. Cambridge: Cambridge University Press.

Bauman, Richard, and Joel Sherzer, eds. 1974. Explorations in the Ethnography of Speaking. New York: Cambridge University Press.

Ben-Amos, Dan. 1971. Toward a Definition of Folklore in Context. Journal of American Folklore 84: 3-15. [CrossRef] Bernstein, Basil. 1971. Class, Codes, and Control. London: Routledge and Keegan Paul.

Bloch, Maurice. 1974. Symbols, Song, Dance and Features of Articulation: Is Religion an Extreme Form of Traditional Authority? European Journal of Sociology 15: 55-81. [CrossRef]

Boas, Franz. 1925. Stylistic Aspects of Primitive Literature. Journal of American Folklore 38: 329-39. [CrossRef]

Briggs, Charles. 1988. Competence in Performance: The Creativity of Tradition in Mexicano Verbal Art. Philadelphia: University of Pennsylvania Press.

Briggs, Charles. 2008. Disciplining Folkloristics. Journal of Folklore Research 45: 91-105. [CrossRef]

Briggs, Charles, and Richard Bauman. 1992. Genre, Intertextuality, and Social Power. Journal of Linguistic Anthropology 2: 131-72. [CrossRef]

Brown, Michael. 1984. The Role of Words in Aguaruna Hunting Magic. American Ethnologist 11: 545-58. [CrossRef]

Brown, Penelope, and Stephen Levinson. 1978. Politeness: Some Universals in Language Usage. Cambridge: Cambridge University Press.

Burke, Kenneth. 1941. The Philosophy of Literary Form. Berkeley: University of California Press.

Cara, Ana. 2003. The Poetics of Creole Talk: Toward an Aesthetic of Argentine Verbal Art. Journal of American Folklore 116: 36-56. [CrossRef]

Cashman, Ray. 2011. Storytelling on the Northern Irish Border: Characters and Community. Bloomington: Indiana University Press.

Chomsky, Noam. 1957. Syntactic Structures. The Hague: Mouton.

Chomsky, Noam. 1965. Aspects of the Theory of Syntax. Cambridge: MIT Press. 
Cocq, Coppélie. 2015. Indigenous Voices on the Web: Folksonomies and Endangered Languages. Journal of American Folklore 128: 273-85. [CrossRef]

De Saussure, Ferdinand. 1959. Course in General Linguistics. New York: McGraw-Hill.

Dégh, Linda. 1969. Folktales and Society: Storytelling in a Hungarian Peasant Community. Translated by Emily Schossberger. Bloomington: Indiana University Press.

Dundes, Alan. 1964. Texture, Text, and Context. Southern Folklore Quarterly 28: 251-65.

Feld, Stephen. 1982. Sound and Sentiment: Birds, Weeping, Poetics and Song in Kaluli Expression. Philadelphia: University of Pennsylvania Press.

Finnegan, Ruth. 1969. How to Do Things with Words: Performative Utterances among the Limba of Sierra Leone. Man 4: 537-52. [CrossRef]

Foley, John Miles. 1991. Immanent Art: From Structure to Meaning in Traditional Oral Epic. Bloomington: Indiana University Press.

Foster, Michael. 1974. When Words Become Deeds: An Analysis of Three Iroquois Longhouse Speech Events. In Explorations in the Ethnography of Speaking. Edited by Richard Bauman and Joel Sherzer. Cambridge: Cambridge University Press, pp. 354-67.

Fox, James. 1974. Our Ancestors Spoke in Pairs: Rotinese Views of Language, Dialect, and Code. In Explorations in the Ethnography of Speaking. Edited by Richard Bauman and Joel Sherzer. Cambridge: Cambridge University Press, pp. 65-85.

Frake, Charles. 1964. How to Ask for a Drink in Subanun. American Anthropologist 66: 127-32. [CrossRef]

Garvin, Paul, ed. 1964. A Prague School Reader on Esthetics, Literary Structure, and Style. Washington: Georgetown University Press.

George, Kenneth. 1993. Lyric, History, and Allegory, or the End of Headhunting Ritual in Upland Sulawesi. American Ethnologist 20: 696-716. [CrossRef]

Georges, Robert. 1969. Toward an Understanding of Storytelling Events. Journal of American Folklore 82: 313-28. [CrossRef]

Glassie, Henry. 1982. Passing the Time in Ballymenone: Culture and History of an Ulster Community. Philadelphia: University of Pennsylvania Press.

Goffman, Erving. 1967. Interaction Ritual: Essays in Face to Face Behavior. Chicago: Aldine.

Goffman, Erving. 1974. Frame Analysis: An Essay on the Organization of Experience. New York: Harper \& Row.

Goffman, Erving. 1981. Forms of Talk. Philadelphia: University of Pennsylvania Press.

Gossen, Gary. 1971. Chamula Genres of Verbal Behavior. Journal of American Folklore 84: 45-68. [CrossRef]

Gossen, Gary. 1978. Chamula Genres of Verbal Behavior. In Verbal Art as Performance. Edited by Richard Bauman. Prospect Heights: Waveland Press, pp. 81-116.

Gravot, Dana David. 2015. 'All I Depend on Is the Lord': Healing Words and Silence in Cajun Traitement. Journal of American Folklore 128: 179-94. [CrossRef]

Grice, H. Paul. 1978. Further Notes on Logic and Conversation. In Syntax and Semantics, Pragmatics. Edited by Peter Cole. New York: Academic Press, vol. 9, pp. 113-27.

Gumperz, John. 1982. Discourse Strategies. London: Cambridge University Press.

Gumperz, John, and Dell Hymes, eds. 1972. Directions in Sociolinguistics: The Ethnography of Communication. New York: Holt, Rinehart and Winston.

Hanks, William F. 1987. Discourse Genres in a Theory of Practice. American Ethnologist 14: 668-92. [CrossRef]

Hymes, Dell. 1964a. Introduction: Toward Ethnographies of Communication. American Anthropologist 66: 1-34. [CrossRef]

Hymes, Dell. 1964b. Language in Culture and Society: A Reader in Linguistics and Anthropology. New York: Harper \& Row. Hymes, Dell. 1971. The Contribution of Folklore to Sociolinguistic Research. Journal of American Folklore 84: 42-50. [CrossRef]

Hymes, Dell. 1972. Models of the Interaction of Language and Social Life. In Directions in Sociolinguistics: The Ethnography of Communication. Edited by John Gumperz and Dell Hymes. New York: Holt, Rinehart and Winston, pp. 35-71.

Hymes, Dell. 1974. Foundations in Sociolinguistics: An Ethnographic Approach. Philadelphia: University of Pennsylvania Press.

Hymes, Dell. 1975a. Folklore's Nature and the Sun's Myth. Journal of American Folklore 88: 346-69. [CrossRef] 
Hymes, Dell. 1975b. Breakthrough into Performance. In Folklore: Performance and Communication. Edited by Dan Ben-Amos and Kenneth Goldstein. The Hague: Mouton, pp. 11-74.

Hymes, Dell. 1981. "In Vain I Tried to Tell You": Essays in Native American Ethnopoetics. Philadelphia: University of Pennsylvania Press.

Irvine, Judith. 1979. Formality and Informality in Communicative Events. American Anthropologist 81: 773-90. [CrossRef]

Jakobson, Roman. 1960. Closing Statement: Linguistics and Poetics. In Style in Language. Edited by Thomas A. Sebeok. Cambridge: MIT Press, pp. 350-77.

Jakobson, Roman. 1966. Grammatical Parallelism and Its Russian Facet. Language 42: 399-429. [CrossRef]

Jakobson, Roman. 1968. Poetry of Grammar and Grammar of Poetry. Lingua 21: 597-609. [CrossRef]

Jansen, William. 1957. Classifying Performance in the Study of Verbal Folklore. In Studies in Folklore: In Honor of Distinguished Service Professor Stith Thompson. Edited by W. Edson Richmond. Bloomington: Indiana University Press, pp. 110-18.

Kermode, Frank. 1979. The Genesis of Secrecy: On the Interpretation of Narrative. Cambridge: Harvard University Press.

Kroskrity, Paul, and Anthony Webster, eds. 2015. The Legacy of Dell Hymes: Ethnopoetics, Narrative Inequality, and Voice. Bloomington: Indiana University Press.

Labov, William. 1966. The Social Stratification of English in New York City. Washington: Center for Applied Linguistics.

Labov, William. 1972. Language in the Inner City: Studies in the Black English Vernacular. Philadelphia: University of Pennsylvania Press.

Labov, William. 2013. The Language of Life and Death: The Transformation of Experience in Oral Narrative. Cambridge: Cambridge University Press.

Labov, William, and Joshua Waletzky. 1967. Narrative Analysis: Oral Versions of Personal Experience. In Essays on the Verbal and Visual Arts. Edited by June Helm. Seattle: University of Washington Press.

List, George. 1963. The Boundaries of Speech and Song. Ethnomusicology 7: 1-16. [CrossRef]

Lord, Albert. 1960. The Singer of Tales. Cambridge: Harvard University Press.

Malinowski, Bronislaw. 1923. Argonauts of the Western Pacific. New York: Dutton.

McDowell, John. 1972. The Mexican Corrido: Formula and Theme in a Ballad Tradition. Journal of American Folklore 85: 205-20. [CrossRef]

McDowell, John. 1979. Children's Riddling. Bloomington: Indiana University Press.

McDowell, John. 1983. The Semiotic Constitution of Kamsá Ritual Language. Language in Society 12: $23-46$.

McDowell, John. 1985. The Poetic Rites of Conversation. Journal of Folklore Research 22: 113-32.

McDowell, John. 1990. The Community-building Mission of Kamsá Ritual Language. Journal of Folklore Research 27: $67-84$.

McDowell, John. 1992. Folklore as Commemorative Discourse. Journal of American Folklore 105: 403-23. [CrossRef]

McDowell, John. 2000. Poetry and Violence: The Ballad Tradition of Mexico's Costa Chica. Champaign: University of Illinois Press.

Mould, Tom. 2005. The Paradox of Traditionalization: Negotiating the Past in Choctaw Prophetic Discourse. Journal of Folklore Research 42: 255-94. [CrossRef]

Mukarovsky, Jan. 1964. The Esthetics of Language. In A Prague School Reader on Esthetics, Literary Structure and Style. Edited by Paul Garvin. Washington: Georgetown University Press, pp. 31-69.

Murray, David. 1977. Ritual Communication: Some Considerations Regarding Meaning in Navajo Ceremonials. In Symbolic Anthropology: A Reader in the Study of Symbols and Meanings. Edited by Janet Dolgin, David Kemnitzer and David Schneider. New York: Columbia University Press, pp. 195-220.

Paredes, Américo. 1964. Some Aspects of Folk Poetry. Texas Studies in Literature and Language 6: 213-25.

Peek, Phillip. 1981. The Power of Words in African Verbal Arts. Journal of American Folklore 94: 19-43. [CrossRef]

Rosaldo, Michelle. 1972. 'I Have Nothing to Hide': The Language of Ilongot Oratory. Language in Society 2: 193-223. [CrossRef]

Rosaldo, Michelle. 1982. The Things We Do with Words: Ilongot Speech Acts and Speech Act Theory. Language in Society 11: 203-35. [CrossRef]

Rosenberg, Bruce. 1970. The Art of the American Folk Preacher. New York: Oxford University Press.

Rudy, Jill. 2002. Toward an Assessment of Verbal Art as Performance: A Cross-Disciplinary Citation Study with Rhetorical Analysis. Journal of American Folklore 115: 5-27. 
Savoleinen, Ulla. 2017. The Return: Intertextuality of the Reminiscing of Karelian Evacuees in Finland. Journal of American Folklore 130: 166-92. [CrossRef]

Searle, John. 1969. Speech Acts: An Essay in the Philosophy of Language. Cambridge: Cambridge University Press.

Sherzer, Joel. 1978. Cuna Ikala: Literature in San Blas. In Verbal Art as Performance. Edited by Richard Bauman. Prospect Heights: Waveland Press, pp. 133-50.

Sherzer, Joel. 1983. Kuna Ways of Speaking: An Ethnographic Perspective. Austin: University of Texas Press.

Silverstein, Michael. 1976. Shifters, Linguistic Categories, and Cultural Descriptions. In Meaning in Anthropology.

Edited by Keith Basso and Henry Selby. Albuquerque: University of New Mexico Press, pp. 11-55.

Tambiah, Stanley Jeyaraja. 1968. The Magical Power of Words. Man 3: 175-208. [CrossRef]

Tannen, Deborah. 1989. Talking Voices: Repetition, Dialogue, and Imagery in Conversational Discourse. Cambridge: Cambridge University Press.

Tedlock, Dennis. 1971. On the Translation of Style in Oral Narrative. Journal of American Folklore 84: 114-33. [CrossRef]

Tedlock, Dennis. 1972. Finding the Center: Narrative Poetry of the Zuni Indians. From performances in Zuni by Andrew Peynetsa and Walter Sanchez; New York: Dial.

Tedlock, Dennis. 1976. From Prayer to Reprimand. In Language in Religious Practice. Edited by William Samarin. Rowley: Newbury House, pp. 72-83.

Toelken, Barre. 1969. The 'Pretty Language' of Yellowman: Genre, Mode, and Texture in Navajo Coyote Narratives. Genre 2: 211-35.

Turner, Victor. 1969. The Ritual Process: Structure and Anti-Structure. Chicago: Aldine.

Urban, Greg. 1986. Ceremonial Dialogues in South America. American Anthropologist 88: 371-86. [CrossRef]

Van Dijk, Teun. 1977. Text and Context. Explorations in the Semantics and Pragmatics of Discourse. London: Longman. Van Gennep, Arnold. 1960. The Rites of Passage. Chicago: University of Chicago Press.

Yankah, Kwesi. 1991. Power and the Circuit of Formal Talk. Journal of Folklore Research 28: 1-22.

Yankah, Kwesi. 1995. Speaking for the Chief: Okyeame and the Politics of Akan Royal Oratory. Bloomington: Indiana University Press.

(C) 2018 by the author. Licensee MDPI, Basel, Switzerland. This article is an open access article distributed under the terms and conditions of the Creative Commons Attribution (CC BY) license (http:/ / creativecommons.org/licenses/by/4.0/). 